\title{
Batteries: an important piece in the puzzle of renewable energies for a better world
}

\author{
Reza Younesi* \\ Department of Energy Conversion and Storage, Technical University of Denmark, Roskilde, Denmark \\ ${ }^{*}$ Correspondence: reyo@dtu.dk \\ Edited by: \\ Zhengcheng Zhang, Argonne National Laboratory, USA \\ Reviewed by: \\ Lei Li, Shanghai Jiao Tong University, China \\ Hui Xia, Nanjing University of Science and Technology, China
}

Keywords: batteries, electric vehicles, lithium batteries, grid application, energy storage

Along with the rapid growth in the world population, the concerns regarding the production and consumption of energy originating from fossil fuels have been increasing in recent years. Therefore, there is higher demand to develop "clean" renewable energies to reduce the use of fossil fuel.

\section{ENVIRONMENTAL PERSPECTIVE}

Most people today are aware of environmental issues related to consumption of fossil fuels. Global warming and consequent unwanted changes in the chemistry of our planet, as a result of greenhouse gas emissions, is a chief concern, which motivates investments to replace fossil fuels by renewable energies. In the year 2000, the annual $\mathrm{CO}_{2}$ emission from the combustion of fossil fuels surpassed 6.7 Gt C (gigaton of carbon) (Smil, 2003), and further increased to $9 \mathrm{Gt}$ in the year 2010 (Peters et al., 2011). Therefore, to protect the Earth's atmosphere and minimize global warming many countries have presented plans to reduce greenhouse gas emissions. For example, the European Union has planned for an $80 \%$ reduction in its 1990 greenhouse gas emissions by the year 2050 (Swedish Energy Agency, 2013).

\section{POLITICAL PERSPECTIVE}

The instability of oil prices and resources is another major factor in the drive for renewable energy. The dependency on oil, which is distributed in limited areas in the world's so-called "energy strategic ellipse" (Armaroli and Balzani, 2007), is potentially a threat to the world economy as well as to world peace. The US, China, and EU are the largest importers of crude oil, while Saudi
Arabia, Russia, Nigeria, and Iran are among the largest exporters of crude oil (International Energy Agency, 2012). Though recent advances in the production of shale gas, as an alternative to oil, might change the map of oil importers/exporters, oil is still very important source of energy and/or political power for many countries. The "oil business" often has indirectly resulted in abuse of human rights in different countries. For example, the clerical regime in Iran with the highest number of executions per capita in the world is widely viewed as one of the worst countries regarding the violation of human right conventions (Amnesty International, 2013). However, the regime has had such a big oil-originated power to oppress people in the country and often threaten global peace and security. Therefore, the liberation of people from oppression and ensuring global security is another often seldom considered motivation for finding an alternative to an oildriven energy economy. Furthermore, the dependency of the US economy on oil has in many occasions played an important factor in its military involvement in several controversial incidents over the years (Klare, 2005). A sentence by former US President Jimmy Carter is an example indicating how US economic and foreign policy are inextricably linked to the consumption of oil:

"The US would use any means necessary, including military forces, to keep the oil flowing" (Klare, 2005).

Thus, considering the environmental and political troubles originating from the huge consumption of fossil fuels, further developments of renewable energies can lead to a better life situation for everyone around the world. In such a development, advanced energy storage technologies such as batteries, supercapacitors, flywheels, etc. play key roles, especially as they can be combined with sustainable energy systems such as wind, solar, and hydropower. Key to the realization of this future is efficient energy storage systems, and in this respect "batteries" have potentials to provide the most realistic solution.

\section{BATTERIES}

A battery can store chemical energy and convert it into electrical energy when it is needed. The history of batteries dates to 200 BC when a battery called the "Baghdad Battery" was used in the Parthian era. This battery was made up of a copper cylinder and iron rod, but it is not clear in what capacity it was used (Frood, 2003; Palacin, 2009). However, the real birth of battery technology is attributed to Alessandro Volta of the voltaic pile in 1800 (Palacin, 2009). Since then, hundreds of different chemical reactions have been utilized to create battery systems including the development of lead-acid, nickel-metal hydride $(\mathrm{Ni}-\mathrm{MH})$, nickel-cadmium (Ni$\mathrm{Cd})$, sodium-sulfur $(\mathrm{Na}-\mathrm{S})$, flow batteries, lithium-ion, sodium-ion, and metalair batteries (Linden and Reddy, 2001; Goodenough and Kim, 2009).

In the path to the resplendence of fossil fuels by advanced renewable energy systems, batteries can be valuable to overcome two main sources of dependency to fossil fuels: transportation and grid applications (Vazquez et al., 2010; Zhang, 2013). An enormous amount of research is now being conducted around the world to fulfil 
the challenging requirements for these two applications.

According to the European energy policy, $10 \%$ of the energy required in the transport sector shall be provided by renewable energies by the year 2020. To achieve this goal, several targets have been defined such as:

"No more conventionally-fueled cars in cities by 2050" (European Commission, 2011).

Though batteries have been utilized in vehicles for more than a century, recent progresses especially in lithium batteries has raised hopes to produce all-electricvehicles (EV) that can be used for longer driving ranges and longer life span. In this context, the US department of energy has set goals of specific energy of $40 \mathrm{kWh}$, 1000 cycle life in 10 years of life, and system price of $\$ 6000$ for batteries in EVs (Cairns and Albertus, 2010). System costs and life span remain major challenges for today's lithium battery technology for EVs. It is well-known that the performance of lithium batteries diminishes during operation in long spanning applications, e.g., due to operation at high temperature or high power. Thus, it is still uncertain how lithium batteries can perform in EVs in 10 years of operation in different temperatures. The cost of lithium batteries is mainly from "materials" used in the batteries, particularly "cathode materials" contribute significantly to the cost of lithium batteries (Cairns and Albertus, 2010). New generation of advanced lithium batteries such as lithium-air $\left(\mathrm{Li}-\mathrm{O}_{2}\right)$ and lithiumsulfur (Li-S) batteries have potential to increase practical specific energy of lithium batteries at least two to three times (Bruce et al., 2012; Younesi, 2012; Younesi et al., 2014). This can, consequently, lead to a decrease in the cost of lithium batteries however, these new battery technologies have not yet been commercialized. Further research should be performed to improve rechargeability, life cycle, specific power, safety, and other issues of $\mathrm{Li}-\mathrm{O}_{2}$ and $\mathrm{Li}-\mathrm{S}$ batteries in order to utilize them in EVs.
For the stationary grid application, the $\mathrm{Na}-\mathrm{S}$ battery technology is today commercially available with approximately 200 installations in the world providing $315 \mathrm{MW}$ of discharge power capacity (Dunn et al., 2011). The Na-S battery, however, works at a high temperature $\left(270^{\circ} \mathrm{C}\right)$ and still suffers from safety issues, especially after the fire at the Tsukuba Plant (Joso City, Ibaraki Prefecture) power plant in September 2011 due to the malfunction of one of the $\mathrm{Na} / \mathrm{S}$ cells (NGK Insulators, 2012). Alternative battery technologies like lithium-ion and redox-flow batteries are now considered for the grid application.

Further developments of different battery systems enable them to meet prerequisites - for example: lower cost, higher energy density, higher power density, higher safety, and cycle life for larger application in EVs as well as for the stationary energy storage.

\section{REFERENCES}

Amnesty International. (2013). Death Penalty 2012: Despite Setbacks, A Death Penalty-Free World Came Closer. Available at: http://www.amnesty.org/en/ news/death-penalty-2012-despite-setbacks-deathpenalty-free-world-came-closer-2013-04-10-0

Armaroli, N., and Balzani, V. (2007). The future of energy supply: challenges and opportunities. Angew. Chem. Int. Ed. Engl. 46, 52-66. doi:10.1002/ anie. 200602373

Bruce, P. G., Freunberger, S. A., Hardwick, L. J., and Tarascon, J.-M. (2012). Li-O $\mathrm{O}_{2}$ and Li-S batteries with high energy storage. Nat. Mater. 11, 19-29. doi:10.1038/nmat3191

Cairns, E. J., and Albertus, P. (2010). Batteries for electric and hybrid-electric vehicles. Annu. Rev. Chem. Biomol. Eng. 1, 299-320. doi:10.1146/annurevchembioeng-073009-100942

Dunn, B., Kamath, H., and Tarascon, J.-M. (2011). Electrical energy storage for the grid: a battery of choices. Science 334, 928-935. doi:10.1126/science. 1212741

European Commission. (2011). White Paper on Transport - Roadmap to a Single European Transport Area-Towards a Competitive and Resource-Efficient Transport System.

Frood, A. (2003). "Riddle of "Baghdad"s batteries," in BBC News Website. Available at: http://news.bbc.co. $\mathrm{uk} / 2 / \mathrm{hi} /$ science/nature/2804257.stm

Goodenough, J. B., and Kim, Y. (2009). Challenges for rechargeable Li batteries. Chem. Mater. 22, 587-603. doi:10.1021/cm901452z
International Energy Agency. (2012). Key World Energy Statistics. Paris: IEA.

Klare, M. (2005). Blood and Oil. New York: Penguin Group.

Linden, D., and Reddy, T. (2001). Handbook of Batteries. New York: McGraw-Hill.

NGK Insulators. (2012). QઐA Concerning the NAS Battery Fire. Available at: http://www.ngk.co.jp/ english/announce/111031_nas.html

Palacin, M. R. (2009). Recent advances in rechargeable battery materials: a chemist's perspective. Chem. Soc. Rev. 38, 2565-2575. doi:10.1039/ b820555h

Peters, G. P., Marland, G., Le Quéré, C., Boden, T., Canadell, J. G., Raupach, M. R., et al. (2011). Rapid growth in $\mathrm{CO}_{2}$ emissions after the 2008-2009 global financial crisis. Nat. Clim. Chang. 2, 2-4. doi:10.1038/nclimate1332

Smil, V. (2003). Energy at the Crossroads. London: The MIT Press.

Swedish Energy Agency. (2013). Energy in Sweden 2012. Eskilstuna: SEA.

Vazquez, S., Lukic, S. M., Galvan, E., Franquelo, L. G., and Carrasco, J. M. (2010). Energy storage systems for transport and grid applications. IEEE Trans. Ind. Electron. 57, 3881-3895. doi:10.1109/ TIE.2010.2076414

Younesi, R. (2012). Characterization of Reaction Products in the $\mathrm{Li}-\mathrm{O}_{2}$ Battery Using Photoelectron Spectroscopy. Ph.D. thesis. Available at http://urn.kb.se/ resolve?urn=urn:nbn:se:uu:diva- 183887

Younesi, R., Norby, P., and Vegge, T. (2014). A new look at the stability of dimethyl sulfoxide and acetonitrile in $\mathrm{Li}-\mathrm{O}_{2}$ batteries. ECS Electrochem. Lett. 3, A15-A18. doi:10.1149/2.001403eel

Zhang, S. S. (2013). Status, opportunities, and challenges of electrochemical energy storage. Front. Energy Res. 1:8. doi:10.3389/fenrg.2013.00008

Conflict of Interest Statement: The author declares that the research was conducted in the absence of any commercial or financial relationships that could be construed as a potential conflict of interest.

Received: 18 February 2014; paper pending published: 10 March 2014; accepted: 01 April 2014; published online: 14 April 2014.

Citation: Younesi R (2014) Batteries: an important piece in the puzzle of renewable energies for a better world. Front. Energy Res. 2:14. doi: 10.3389/fenrg.2014.00014 This article was submitted to Energy Storage, a section of the journal Frontiers in Energy Research.

Copyright (c) 2014 Younesi. This is an open-access article distributed under the terms of the Creative Commons Attribution License (CC BY). The use, distribution or reproduction in other forums is permitted, provided the original author(s) or licensor are credited and that the original publication in this journal is cited, in accordance with accepted academic practice. No use, distribution or reproduction is permitted which does not comply with these terms. 